\title{
Developing Plot Level Database on Land Accretion: A Case Study on Sandwip Island of Bangladesh
}

\author{
Irtifa Alam Nabila \\ Lecturer, Department of Disaster and Human Security Management, \\ Bangladesh University of Professionals \\ Mirpur-12, Dhaka-1216, Bangladesh \\ E-mail: irtifa.alam@bup.edu.bd
}

Received: June 5, 2019 Accepted: July 10, 2019 Published: July 12, 2019

doi: 10.5296/jsss.v6i2.15078 URL: https://doi.org/10.5296/jsss.v6i2.15078

\begin{abstract}
Erosion and accretion are continuously changing the shape, size and configuration of Sandwip Island of Bangladesh. Plot level database are very significant in order to document these changes from micro levels. For this purpose, an attempt has been made to develop plot level database about land accretion of the Island since 1913 through overlapping Mauza maps using GIS (Geographic Information System) data. Here a case study named Thak Kuchiamora mauza, experiencing alluvion located in the eastern side of the Sandwip Island has been presented from micro level. Both primary and secondary data have been used for this study. CS (Cadastral Survey) and RS (Revisional Settlement) mauza maps available from DLRS (Directorate of land records and Surveys) office has been collected and overlaid on satellite image (2016) so that the accretion context and circumstances can be detected. Plot level information has been extracted from collected mauza maps and integrating with present land cover features the changing scenario has been analysed. During cadastral survey, 172 plots have been recorded and in the Revisional settlement operation it increased into 502 plots due to land fragmentation. From 1970 to 2000 period the area accreted about $220 \mathrm{~m}$ from southwest to northeast direction. Analyzing accreted database over different periods it has been concluded that from Revisional settlement operation (1970) to 2016 it has been recorded that the mauza has increased about $1185 \mathrm{~m}$ from west to east. The newly formed landmass of the area hasn't stable enough for permanent land use yet.
\end{abstract}

Keywords: Mauza maps, Plot, Land accretion, Sandwip, GIS 


\section{Introduction}

Island dwellers are often characterized as more vulnerable and marginalized than the mainland (Rampengan, 2014). Sandwip Island is located in the lower Meghna estuary of Bangladesh which is undergoing numerous changes (Hasan, 2011). The Island's shape and area has been dramatically changing with erosion in the western part and accretion in the eastern part (Sarwar, 2013). The channels in between Sandwip and Noakhali are progressively silting up in natural way (Khan, 2008). As a result, new landmass is adding with the main land of the Island at the eastern side. The eastern coast seems lower, but an encircling embankment protects it (Uddin, 2015). In satellite image, a vast newly reformed landmass has been seen in Thak Kuchiamora mauza. This study has been done with help of mauza database. Smallest revenue rural geographic unit having jurisdiction list number and having at least 200 acres land is called mauza. Maps showing the individual piece of land called "parcel" or "plot" is prepared accurately, following a big scale by detailed survey technique is called Mauza map (Sarkar, 2012). Mauza map contains plot level information (Paul, 2014) and there are thousands of plots in each sheet of studied mauza. Different land cover features are found in different plot having individual dag number. An attempt has been taken to develop plot level database about newly formed landmass with necessary information. The main aim of the study is therefore, to develop plot level database on land accretion of Sandwip Island so that changes of the Island can be documented using mauza maps.

Accretion of land by movement of water is known as Alluvion (Islam, 2013). Land alluvion can be three types: (1) Re-appearance of a land lost by diluvion. (2) Gradual enhancement of a land on the bank of a river (3) Any other land (Salauddin, 2005). Accretion process is probably due to the backwash sediment deposition from the Sandwip channel, relatively gentle slope of bank which facilitates natural sediment deposition carried by the channel and the Meghna estuary (Emran, 2019). Thak Kuchiamora mauza is studied as a sample of land alluvion where gradual sedimentation has been observed in recent years.
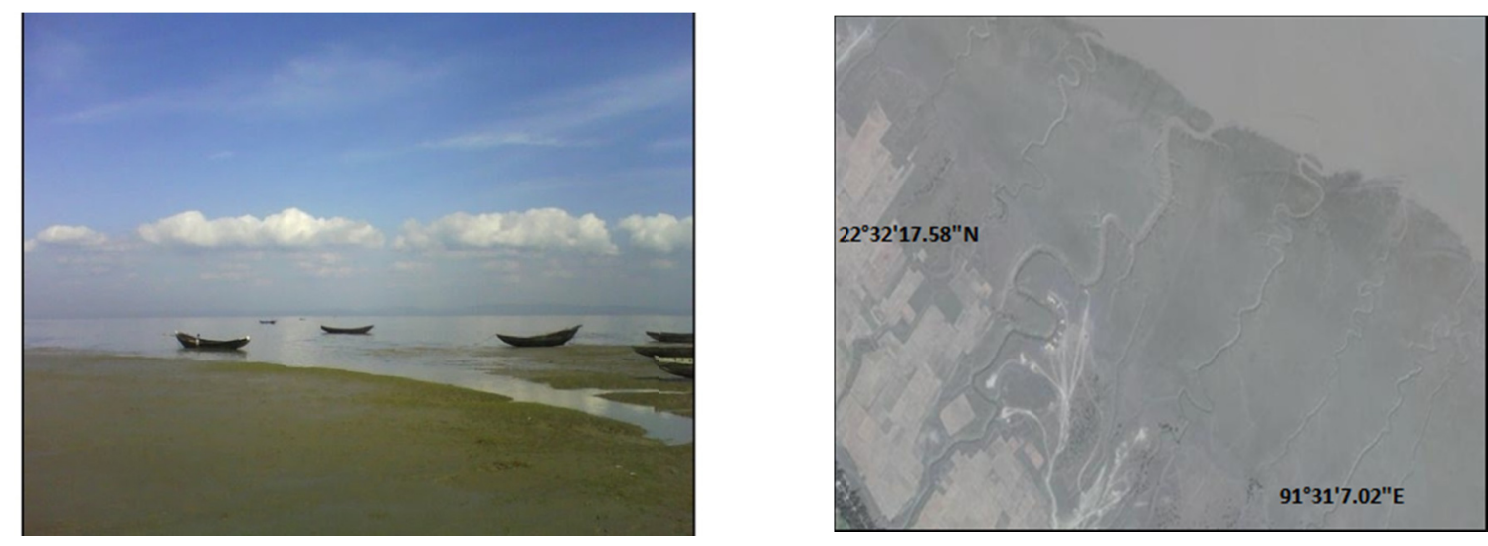

Figure 1. Part of Thak Kuchiamora, new lands are adding with the main land (Source: Field Survey)

Land is the most significant source of survival, most valuable natural asset and is central to 
the majority population for its livelihood (Salauddin, 2005). Land management evolved along with human civilization. In ancient period man managed land in their own system and necessity. Survey of land has a long history that dates back to systems developed by the Hindu rulers of ancient India and carried the heavy imprint of the elaborate system of land surveys and registration for revenue collection purposes introduced by the British. Mauza maps are indispensable tool for the administration, management and planning projects (Paul, 2014).

A cadastral map shows the boundaries of all land parcels on large scale generally in 16 inches $=1$ mile. These maps do not have any graticule information. These maps show only the survey numbers and relative location of all land parcels in a given village and attribute information such as: ownership, land use, size and value (Paul, 2014). This attribute information aids in revenue collection and also ensures the legal security of the property to its owners or legal heirs (Khular, 1985). Mauza maps when overlaid on high resolution satellite image help in the monitoring of changes at plot level (Paul, 2014).

\section{Data and Methods}

There has been little research on plot level land accretion survey of Sandwip Island. This study is based on both primary and secondary data. The primary data were collected through field observations, photograph taking and informal interview. Field observations were helpful in understanding the real scenarios. During field visits, the author talked with the chairman and the high school teachers in order to collect socio-economic information of the area. Some local people were very much cooperative in sharing their experiences which helped the author a lot.

Mauza map, Satellite Imageries, published and unpublished works, Articles, Books, Census Reports, Local newspaper etc. were secondary data sources. Mauza sheets in 1:3960 scale was the base map for this study, and they were collected from DLRS (Directorate of Land Records and Surveys) office for Cadastral survey and revisional settlement mauza maps. Firstly, the collected sheets were scanned in 300dpi (dot per inch) to produce raster form. The scanned sheet was not referenced to any geographic location. Thus, to fully utilize the scanned maps in a GIS platform, the sheet was georeferenced and converted to a vector format. In addition to that, real world coordinates were taken from satellite image using features extrapolation method with the aid of overlay analytical tool of Google Earth software or georeferencing the sheets. After that each individual mauza sheet were referenced and then vector format has been created through digitization. Later, Arc GIS 10.2 software has been used for data processing and mapping of the resulted data. Data is presented by table, bar diagrams using Microsoft excel to demarcate the changes.

\section{Study Area}

Thak Kuchiamora mauza is situated in the eastern side of Sandwip Island surrounded by Thak Bauria mauza in the north, Char Kuchiamora mauza in the west and Thak Kochiapar mauza in the south and Sandwip channel in the east. Geographically it is located in between $22^{\circ} 31^{\prime}$ to $22^{\circ} 32^{\prime} \mathrm{N}$ latitudes and in between $91^{\circ} 30^{\prime}$ to $91^{\circ} 31^{\prime}$ E longitudes. 


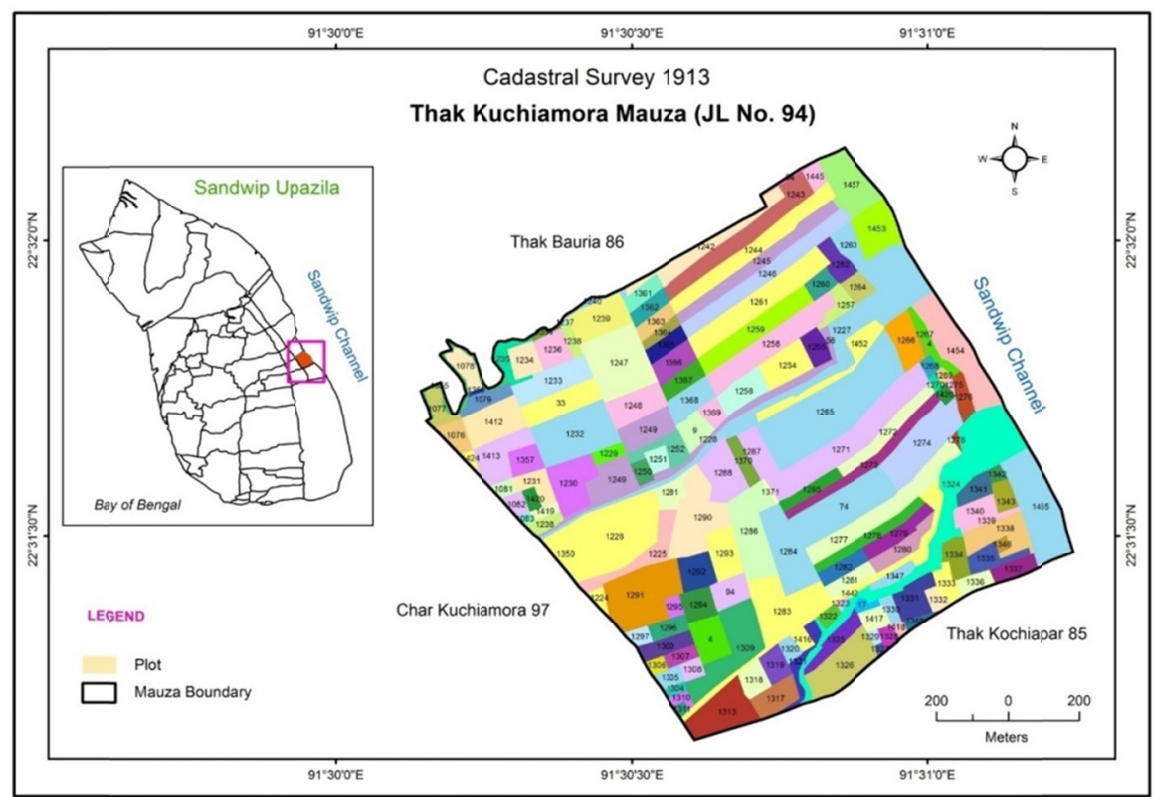

Figure 2. Thak Kuchiamora Mauza Map (CS) (Source: Compiled by Author, 2019)

Table 1. Table showing administrative information of Thak Kuchiamora Mauza

\begin{tabular}{|c|c|c|c|c|c|c|c|}
\hline \multirow[t]{3}{*}{ Study Area } & \multirow[t]{3}{*}{ District } & \multirow[t]{3}{*}{ Upazila } & \multirow[t]{3}{*}{ Union } & \multirow[t]{3}{*}{ Mauza } & \multirow[t]{3}{*}{$\begin{array}{l}\text { Geo } \\
\text { Code }\end{array}$} & \multicolumn{2}{|c|}{$\begin{array}{l}\text { Jurisdiction } \\
\text { No. }\end{array}$} \\
\hline & & & & & & CS & RS \\
\hline & & & & & & Mauza & Mauza \\
\hline Thak & Chittagong & Sandwip & Bauria & Thak & 918 & 94 & 57 \\
\hline $\begin{array}{l}\text { Kuchiamora } \\
\text { mauza }\end{array}$ & & & & Kuchiamora & & & \\
\hline
\end{tabular}

Source: Directorate of Land Records and Surveys.

Table 2. Table showing demographic information

\begin{tabular}{llll}
\hline Mauza Name & Year & Total Population & Households \\
\hline Thak Kuchiamora & 1951 & Uninhabited & - \\
1961 & Uninhabited & - \\
1974 & Uninhabited & - \\
1981 & 460 & 102 \\
1991 & 560 & 138 \\
2001 & 955 & 178 \\
2011 & 1168 & 221 \\
\hline
\end{tabular}

Source: BBS, 1951-2011.

Here it has been found that the eastern side of the Island is not so much populated. Vast area 
of the mauza has agricultural land with visible khals and mangrove forest. Number of settlement and pond is less comparatively the other side of the island.

\section{Mauza Information of the Study Area}

There are 40 mauzas in Sandwip upazila (Banglapedia, 2015). Thak Kuchiamora mauza is in Bauria union of the upazila. Geo code of Thak Kuchiamora is 918 (BBS, 2012). Here, Geo code number refers to Geographic area code number as a digital expression of administrative units for recording statistical data with reference to spatial area (Sarkar, 2012).

\subsection{Information About Studied CS (Cadastral Survey) Mauza}

The Author has extracted the following information about studied mauza:

a. It was made by the authority of Government during 1913-1916.

b. N.B.: Some area is under 'Ka 'survey which was surveyed according to 190c no. in 7.1.1907.

c. Adopted for the purpose of operation under chapter IV of the EBSA and T Act, 1950 without correction.

d. Name of district has been corrected in accordance with the government notification no. 5038 G.A. dated 24.12.1954

e. Plot information:

In Thak Kuchiamora mauza there were 172 plots completed in one sheet.

Table 3. General information about studied CS Mauza

\begin{tabular}{|c|c|c|c|c|c|c|c|c|c|}
\hline \multicolumn{10}{|c|}{ Studied CS (Cadastral Survey) Mauza } \\
\hline \multirow{2}{*}{ Mauza Name } & \multirow{2}{*}{$\begin{array}{l}\text { JL } \\
\text { No. }\end{array}$} & \multirow{2}{*}{ 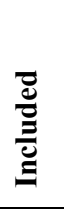 } & \multirow{2}{*}{\multicolumn{2}{|c|}{ 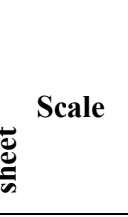 }} & \multirow{2}{*}{ 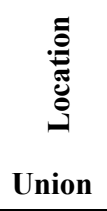 } & \multicolumn{4}{|c|}{ Surrounding area (Mauzas with JL no.) } \\
\hline & & & & & & North & South & East & West \\
\hline \multirow{5}{*}{ Thak Kuchiamora } & \multirow{5}{*}{94} & \multirow{5}{*}{-} & & $16^{\prime \prime}=1$ & \multirow{5}{*}{ 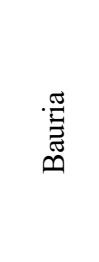 } & \multirow{5}{*}{$\begin{array}{l}\text { Thak } \\
\text { Bauria } \\
86\end{array}$} & \multirow{5}{*}{$\begin{array}{l}\text { Thak } \\
\text { Kochiapar85 }\end{array}$} & \multirow{5}{*}{$\begin{array}{l}\text { Sandwip } \\
\text { channel }\end{array}$} & \multirow{5}{*}{$\begin{array}{l}\text { Char Kuchiamora } \\
97\end{array}$} \\
\hline & & & & mile & & & & & \\
\hline & & & 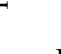 & & & & & & \\
\hline & & & & R.F. & & & & & \\
\hline & & & & $1: 3960$ & & & & & \\
\hline
\end{tabular}

Source: CS Mauza map, 1913.

\subsection{Information about Studied RS (Revisional Settlement) Mauza}

Revisional Settlement is a Revisional survey of cadastral survey and state acquisition survey (Jamil, 2006). This survey was not surveyed as like cadastral period. It was done in order to update land ownership record. Thus, a few corrections have been made in those mauza maps whose one third land have been changed due to alluvion or diluvion (Islam, 2013). 
Table 4. General information about studied RS Mauza

\begin{tabular}{|c|c|c|c|c|c|c|c|c|}
\hline \multirow{2}{*}{$\begin{array}{l}\text { Mauza } \\
\text { Name }\end{array}$} & \multirow{2}{*}{$\begin{array}{l}\text { JL } \\
\text { No. }\end{array}$} & \multirow{2}{*}{ 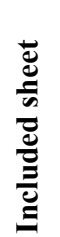 } & \multirow{2}{*}{ Scale } & \multirow{2}{*}{ 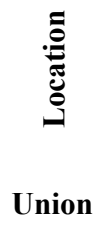 } & \multicolumn{4}{|c|}{ Surrounding area (Mauzas with JL no.) } \\
\hline & & & & & North & South & East & West \\
\hline $\begin{array}{l}\text { Thak } \\
\text { Kuchiamora }\end{array}$ & 57 & - & $\begin{array}{l}16^{\prime \prime}=1 \\
\text { mile } \\
\text { R.F. } \\
1: 3960\end{array}$ & 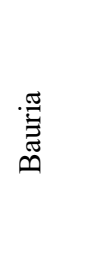 & $\begin{array}{l}\text { Thak } \\
\text { Bauria } \\
54\end{array}$ & $\begin{array}{l}\text { Thak } \\
\text { Kochiapar } \\
53\end{array}$ & $\begin{array}{l}\text { Sandwip } \\
\text { channel }\end{array}$ & $\begin{array}{l}\text { Char } \\
\text { Kuchiamora } \\
61\end{array}$ \\
\hline
\end{tabular}

Source: RS Mauza map, 1970.

Here, JL number refers to jurisdiction list number numerically identifying mauzas cadastral, revenue and administrative purposes within a upazila (Bangladepia,2015).

General information carried by RS mauza map are:

a. Made by the authority of Government during 1970-1985.

b. Plot information:

In Thak Kuchiamora mauza there were 502 plots completes in one sheet.

Above information about selected mauzas have been extracted from collected mauza sheets which is helpful for conducting this study at plot level.

\section{Demarcation of Newly Reformed Landmass}

\subsection{Thak Kuchiamora Mauza during Different Survey Periods}

During cadastral survey, the total area of Thak Kuchiamora mauza was 464 acres. At present time the area has been increasing in its size.

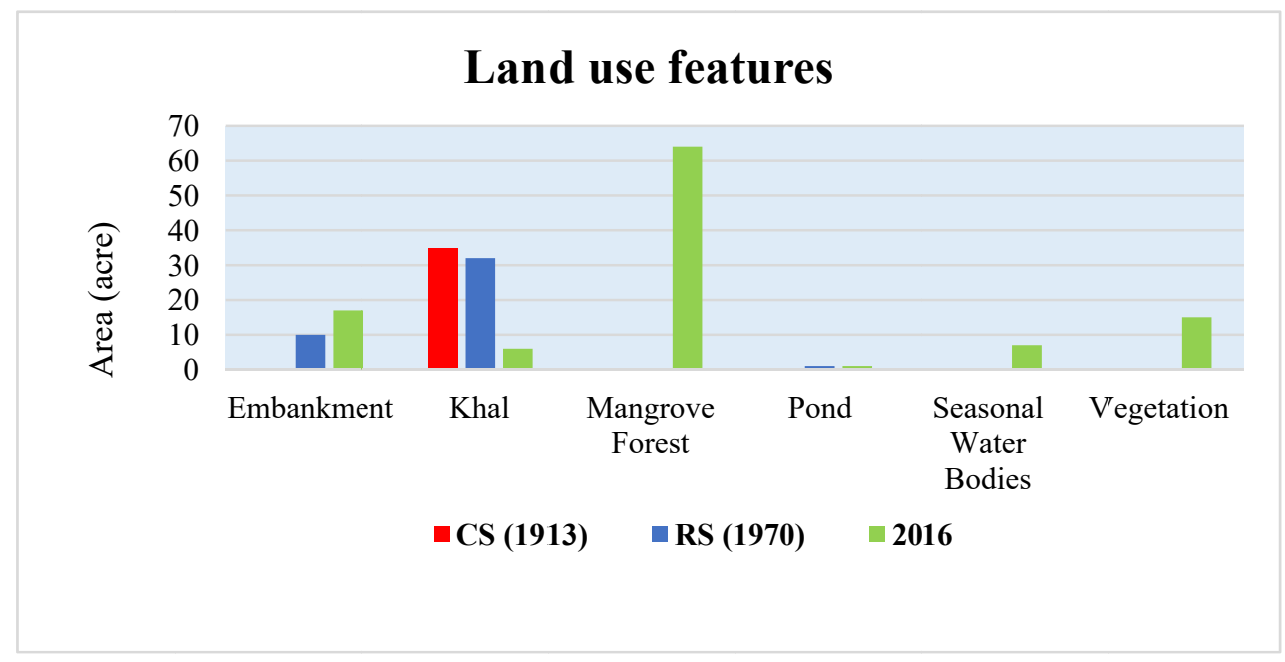

Figure 3. Bar diagram showing land use in different periods

Source: CS and RS mauza map, Satellite Image, 2019. 


\section{NI Macrothink}

From above (Figure 3) it is found that the percentage of area occupying khal has been decreased over time. There was no embankment in the area during CS survey, but presence of an embankment is found during Revisional settlement operation. It is also mentionable that mangrove forest (occupying 64\%) of the study area act as a natural barrier and also help in land accretion process.

\section{Extracting Plot Level Information about accreted Land}

Alluvial land or land thrown up from river is known as Char land (Islam, 2013). Land alluvion involves the addition of sediment to a coastline or riverbank, increasing land area. Thak Kuchiamora mauza is studied as a sample of land alluvion. In the eastern side of the mauza newly reformed land mass have been identified from satellite image. Plot level information about land use of cadastral and Revisional settlement operation has been mentioned for generating an idea about the mauza. For showing added landmass it has been tried to document present land cover features. Integrating mauza map with present satellite image it has been seen that the studied mauza is gaining new landmass every day due to regular sedimentation process.

\subsection{Included Plot with Dag Number}

Included Plot with specific dag number of the selected CS and RS mauza is presented accordingly:

Table 5. Plot information of CS Mauza Map of Thak Kuchiamora

\begin{tabular}{llll}
\hline & \multicolumn{3}{c}{ Thak Kuchiamora CS Mauza } \\
Included & Included Dag No. & \multicolumn{2}{l}{ Features Dag No. } \\
Sheet & & Halot & Khal \\
\hline $\mathbf{1}$ & $1076-1083,1224-1297,1300,1304-1311$, & 1222,1339 & \\
& $1316-1348,1354$ &, 1356, & $1227,1240,1324$, \\
& $1371,1413,1416-1421,1424,1442,1445,1$ & 1442 & $1354,1355,1451$ \\
& $451-1457$ & & \\
& $\mathbf{1 7 2}$ & & \\
\hline
\end{tabular}

Source: CS Mauza map, 1913.

Dag stands for plots. Each and every plot of all settled or unsettled land is given a number named Dag number ("ROR," 2014). The Dag Chitha or Field-index is written according to the Serial Number of the fields in the village. A piece of land within one boundary is possessed by one person or persons jointly. This register is a conclusive proof of the classification of land i.e. whether the land is a Govt. land, a grazing ground, a fishery or a private land (Islam, 2013). Here, Halot (Figure 4) stands for a wide path situated between agricultural lands in which farmer move with his livestock. In rainy season it is used as a creek in which they move with boat (Sarkar, 2012). 


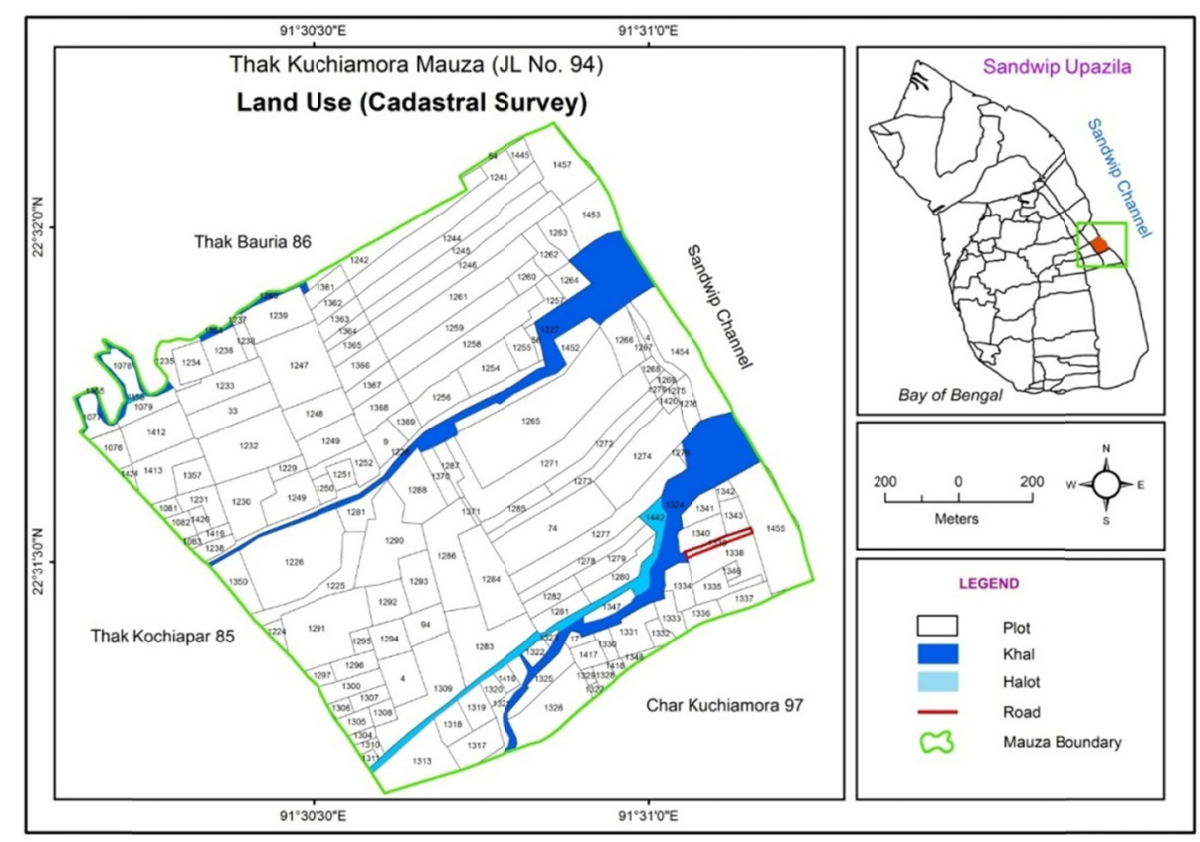

Figure 4. Thak Kuchiamora Mauza map of cadastral survey period has been presented with dag number

Source: Compiled by Author, 2019.

During Revisional settlement operation, the number of plots of Thak Kuchiamora mauza has been increased due to changes of ownership (Table 6).

Table 6. Plot Information of RS Mauza Map of Thak Kuchiamora

\begin{tabular}{lclll}
\hline & \multicolumn{3}{c}{ Thak Kuchiamora RS Mauza } & \\
Included & Dag No. & \multicolumn{2}{c}{ Features Dag No. } & \\
Sheet & & Road & Khal & Embankment \\
\hline $\mathbf{1}$ & $1-5,7-25,27-31,33-87,91-$ & $75,86,154$ & $18,87,241,359,360,361$ & 242 \\
& $100,103,105-117,119-127,1$ & & \\
& $29-135,137-143,146-154,15$ & $461,486,503,512,521,5$ & \\
& $6-164,167-190,192-204,206$ & 06 & \\
& $-216,218-461,463-507,509,5$ & & \\
& $10,512-525$ & & & \\
Total & $\mathbf{5 0 2}$ & & & \\
\hline
\end{tabular}

Source: RS Mauza map, 1970. 


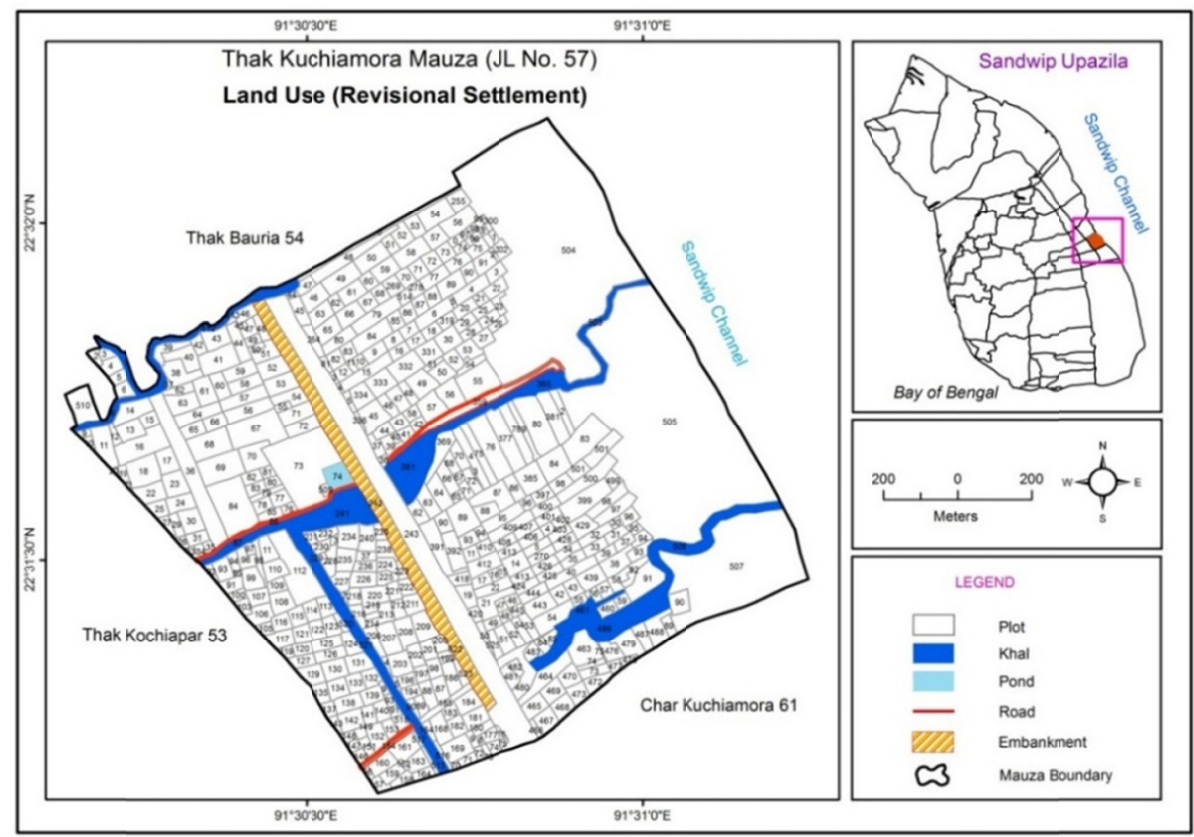

Figure 5. Plot level land use of RS Mauza Map of Thak Kuchiamora

Source: Compiled by Author, 2019.

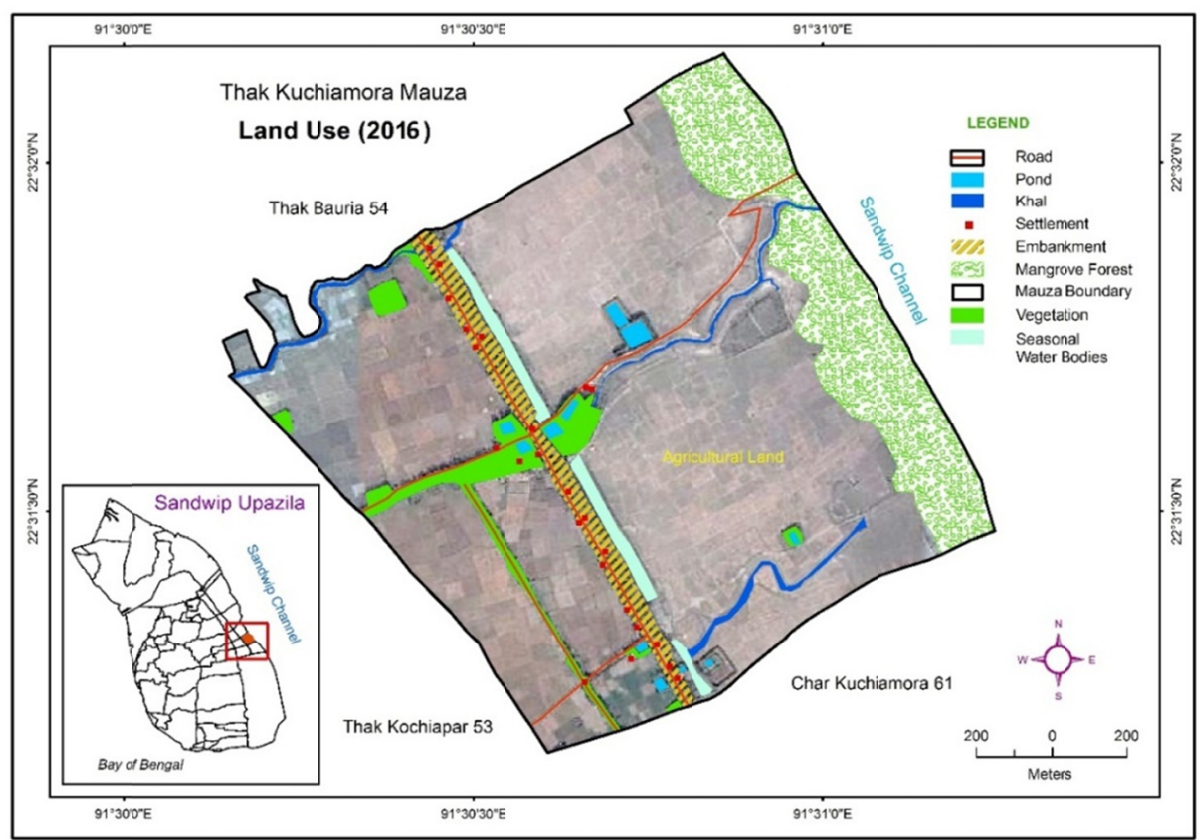

Figure 6. Land Use of Thak Kuchiamora Mauza

Source: Compiled by Author, 2019.

\section{Land Accretion Scenario Analysis}

People of the Sandwip Island are suffering much due to massive erosion for a long period. On 


\section{Macrothink}

the other hand, from satellite imagery and mauza map it has been observed that new landmass is also adding in the eastern areas of the Island due to regular sedimentation process and Thak Kuchiamora mauza is one of them (Nabila,2017).

\subsection{Land Accretion During Different Period}

Visible land accretion has been identified through integrating mauza map with recent satellite image. Boundary data of different years have been prepared and compared to find out the extended area.

\subsection{Measurement of Land Alluvion}

Accretion of landmass of study area has been measured through cross-section method for understanding the alluvion scenario of study mauza.

Table 7. Measurement of accretion during different periods

\begin{tabular}{lll}
\hline Period & Accretion (meter) & Direction \\
\hline $\mathbf{1 9 7 0 - 2 0 0 0}$ & 220 & Southwest $\rightarrow$ Northeast \\
$\mathbf{2 0 0 0 - 2 0 0 5}$ & 41 & \\
$\mathbf{2 0 0 5 - 2 0 1 0}$ & 631 & \\
$\mathbf{2 0 0 5 - 2 0 1 6}$ & 293 & \\
\hline
\end{tabular}

Source: Mauza Map, Satellite Image, 2000-2016.

From available data collected from mauza map and satellite image it has been observed that the land area of the studied mauza has been increasing from southwest to northeast direction. (Table 7).

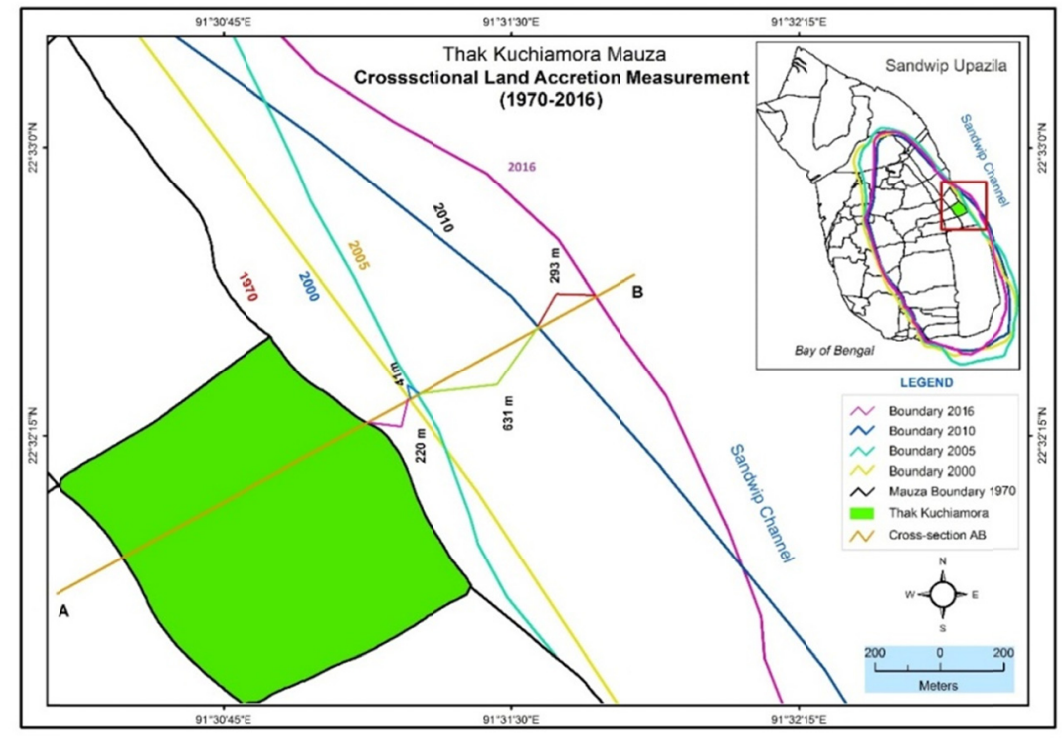

Figure 7. Land accretion during different periods

Source: Compiled by Author from Mauza maps and Satellite Image, 2019. 
From above discussion and measurement, it can be said that the area of Thak Kuchiamora mauza have gained vast new landmass over different periods. From field observation it is found that the added landmass has been using for farming practices. According to local people, this new landmass is a blessing for them. At the same time, local people said that sometimes it creates socio-economic anomalies and other issues. Age-old notions of 'might is right' and 'the survival of the fittest' still govern the char-land (Baqee, 1998). From an informal discussion with the local people it has been found that land capture or power politics is common on the studied mauza. In order to avoid these problems, an effective distribution of reformed land is crucial as it will create massive employment opportunities, reduce rural-urban migration and overall reduce poverty rate.

\section{Conclusion}

Sandwip island of Bangladesh is ecologically sensitive and climatically vulnerable (Najnin, 2014). The study presents an attempt in identifying accreted landmass based on historical CS and RS mauza maps integrating with recent satellite image so that a true picture about the changing nature of the Island can be documented. From overall analysis, it has been found that the Thak Kuchiamora mauza of the island has been increasing in eastward from west. As Sandwip island is notable for its eroding nature, it is worthy of attention to make proper management of newly reformed landmass of this island. In this regard, proper management of the newly reformed land of Thak Kuchiamora mauza can bring a great opportunity to change the livelihood of the Island dwellers.

\section{Acknowledgements}

The author would like to express her gratitude to Dr. Md Shahedur Rashid, Professor, Geography and Environment Department, Jahangirnagar University for his guidance and support. She also thankful to the authority of DLRS (Directorate of Land Records and Surveys) for providing the mauza sheets.

\section{References}

Banglapedia. (2015). National Encyclopedia of Bangladesh. Dhaka: Asiatic Society of Bangladesh, publishing Co. ltd.

Baqee, A. (1998). Peopling in the Land of Allah Jaane (first edition). Dhaka: The University Press Limited.

BBS. (2012). District population census 2011, Chittagong Zilla Series, Bangladesh Bureau of Statistics, Dhaka, Bangladesh.

Emran, A., Rob, M. A., \& Kabir, M. H. (2019). Coastline Change and Erosion-Accretion Evolution of the Sandwip Island, Bangladesh. Environmental Information Systems: Concepts, Methodologies, Tools, and Applications (pp. 1497-1509). IGI Global. https://doi.org/10.4018/978-1-5225-7033-2.ch068

Hasan, S. (2011). A Study on morphological change from Chandpur to Sandwip channel in the Meghna estuary. (Project paper, Bangladesh University of Engineering, and Technology).

Islam, M. A. (2013). Mutation and updating of land records in Bangladesh: a study at Gazipur sadar upazila (Doctoral dissertation, BRAC University).

Jamil, A. (2006). Verification of Documents of Land: Legal Issues and Complications, 
(Dissertation, Dhaka University).

Khan, S. R. (2008, 26 April). Sandwip-Urir Char-Noakhali cross dam for long-term food security. Retrieved from https://www.thedailystar.net/news-detail-33780

Khular, Y. L. (1985). Proceedings of all India cadastral surveys seminar, 16-17 September 1985, Dehradun.

Nabila, I. A., Israd, N., \& Akhtar, N. (2017). Assessment of Coastal Erosion and Accretion Scenario of an Island using Mauza Maps: a GIS Based Case Study of Sandwip Island of Bangladesh, Imperial Journal of Interdisciplinary Research, 3, 438-442. Retrieved from http://www.imperialjournals.com/index.php/IJIR/article/view/5808/0

Najnin, A. (2014). Integrated approach to assess vulnerability of the Coastal Region of Bangladesh due to climate change (Doctoral dissertation).

Paul, A. (2014). Mauza map updating by high resolution satellite images and GIS, Kolkata: Journal of Geomatics, 8(2).

Rampengan, M. M., Boedhihartono, A. K., Law, L., Gaillard, J. C., \& Sayer, J. (2014). Capacities in facing natural hazards: a small island perspective. International Journal of Disaster Risk Science, 5(4), 247-264. https://doi.org/10.1007/s13753-014-0031-4

(ROR) Record of Rights (Khatiyan). (2014, 13 January). Retrieved from http://zaman71.blogspot.com/2014/01/record-of-rights-khatiyan.html

Salauddin, S. (2005). Land Rights and Poverty Alleviation, Bangladesh Legal Aid and Services Trust, Dhaka: PIL and Advocacy Cell.

Sarkar, N. G. (2012). Rules of land mutation, Dhaka: Remisi law books publication.

Sarwar, M. G. M., \& Woodroffe, C. D. (2013). Rates of shoreline change along the coast of Bangladesh. Journal of Coastal Conservation, 17(3), 515-526. https://doi.org/10.1007/s11852-013-0251-6

Uddin, M. M. (2015). Geomorphological Evolution and Vulnerability of Low-Lying Coasts in Bangladesh: The Case Study of Sandwip Island (Doctoral dissertation, Università degli Studi di Ferrara).

\section{Copyright Disclaimer}

Copyright for this article is retained by the author(s), with first publication rights granted to the journal.

This is an open-access article distributed under the terms and conditions of the Creative Commons Attribution license (http://creativecommons.org/licenses/by/3.0/). 